

\title{
Integrating the 'Troublemakers': A Taxonomy for Cooperation between Banks and Fintechs
}

- Research in Progress -

\section{Authors:}

Benedict J. Drasch, André Schweizer, Nils Urbach

FIM Research Center and Project Group Business \& Information Systems Engineering of the Fraunhofer FIT, University of Bayreuth, GERMANY

\begin{abstract}
:
The banking sector has been subject to fundamental changes as digitalization is enabling novel technologydriven banking services and is creating new customer demands. While banks face sluggish innovation processes, fintechs take advantage of the digital era, delivering customer-centric solutions. Although banks have realized that cooperation with fintechs is a key approach to foster innovation, they struggle to address the associated challenges. Yet, there has been very little research into this phenomenon, so as to establish best practices, because neither bank-fintech cooperation, nor associated and relevant characteristics have been evaluated. However, especially from an economic and financial perspective it is crucial to close this research gap to better understand how technology-driven organizations and cooperating with them reshapes the financial sector and therefore entire economies. Thus, we propose a theoretically founded and empirically proven taxonomy. Based on the literature, 136 real-world cases, and 12 expert interviews, our results suggest structuring and describing bank-fintech cooperation through 13 dimensions. Further, the empirical examination allows for the identification of prevailing cooperation patterns. Our findings contribute to theory development on fintechs, their integration into the banking sector, and the crossorganizational cooperation research area. This paper also has practical implications for both banks and fintechs, and opens promising avenues for future research.
\end{abstract}

\section{Keywords:}

Banking, Fintechs, Digital Transformation, Cooperation, Taxonomy 


\section{Introduction}

The banking sector is undergoing fundamental changes owing to digital transformation (Barberis \& Chishti, 2016). This new era challenges existing business practices and established structures (Bharadwaj, El Sawy, Pavlou, \& Venkatraman, 2013; Châlons \& Dufft, 2017). On the one hand, new technologies - also transferred from other business domains - enable new banking applications and services (e.g. crowdlending, online identification services, or blockchain services) (e.g. Schweizer et al., 2017). These developments require appropriate and aligned information technology (IT), which again enables novel applications (e.g. new products or services; technology-push) (cf. Nemet, 2009). On the other hand, digital transformation changes the ways in which customers think and act (e.g. point-of-sale, data privacy) and raises new customer demands (demand-pull) (cf. Nemet, 2009). Further, digital transformation in the banking sector affects IT departments and IT strategies, and transforms business processes and even entire business models (Benlian, Hess, \& Leimeister, 2014). Thus, banks are forced to rethink their current value delivery and customer interactions (Marous, 2013).

Meanwhile, financial technology startup companies (fintechs) are creating new technology-enabled opportunities to fulfill emerging customer-demanded needs or even create novel customer needs. Consequently, the fintech industry is booming and clearly draws attention: Global venture capital investment in fintech companies has increased to U.S. \$24.7 billion in 2016 and reinforced their disruptive capabilities (KPMG, 2017). Fintechs are thought to be by far quicker and more agile than traditional banks in implementing and leveraging such opportunities by employing of innovative technology solutions and customer-centered approaches (Ansari \& Krop, 2012; Christensen, 2013). Consequently, fintechs have become known for being the innovation drivers in the field, and are therefore predicted to play a key role in the financial services industry in the future (Dapp, 2014). Digital transformation and technology advancements also enable services providers to address customers in a very short time. These conditions favor many fintechs working on alternatives to established banking institutions (Shontell, 2015). Therefore, banks need to keep up with the pace of innovation in order to stay in the market, since innovative companies are said to be growing faster, generate higher revenue, and have a higher likelihood of permanent success (Kim \& Mauborgne, 1997). Thus, also in the banking sector, innovation - especially IT innovation - can be considered a key differentiator against competitors, and a critical factor for financial sustainability (Chandy \& Tellis, 2000; Fagerberg, 2004; Schumpeter, 1942; Teece, 2010).

Banking practitioners have realized that banks face several challenges, such as a short-term management focus and a lack of internal capabilities to innovate, leading to long innovation cycles and long times-tomarket (Tornjanski, Marinković, Săvoiu, \& Čudanov, 2015). Thus, banks seek to transform their organizations towards long-term success (Economist Intelligence Unit, 2015). To achieve this, it is crucial to overcome the stated internal problems (Tornjanski et al., 2015) and to create competitive advantages by considering external innovativeness and cooperating with external parties (Chesbrough, 2004; Jaubert, Marcu, Ullrich, Malbate, \& Dela, 2014). In a survey among financial services executives, $80 \%$ of the participants stated that collaboration with startups brings new ideas into their businesses (Skan, Dickerson, \& Masood, 2015). Also, a self-assessment of banks and fintechs reveals a striking match between banks' weaknesses and fintechs' strengths, and vice versa (Economist Intelligence Unit, 2015). Thus, it seems reasonable for banks to evaluate and leverage the potential of external innovation sources originated from startup companies (e.g. acquisitions, alliances, incubations, or joint ventures). Fintechs are not (only) seen

as the source of disruption, but as an opportunity for collaboration and enhancement of innovation (Economist Intelligence Unit, 2015). A key success factor for promising bank-fintech cooperation is to preserve innovative fintech characteristics, embodying the mindset towards new ideas and change, while successfully combining them with banking controls, know-how, processes, and assets (Economist Intelligence Unit, 2015; Hurley \& Hult, 1998; Rogers, 2003). 
However, most banks struggle to meet the challenges and the complexity associated with cooperation scenarios, and the research is lagging behind current developments in the financial sector, especially regarding bank-fintech cooperation (Tornjanski et al., 2015). While previous research has addressed and answered various research questions in the realms of cooperation, innovation, and their coherence, the theory does not fully account for the idiosyncratic nature of bank-fintech cooperation. Although the financial sector is key to almost every economy (McKinnon, 1973; Odedokun, 1996; Schmitt, 1974), to date, neither bank-fintech cooperation, nor associated and relevant characteristics have been analyzed and evaluated. It is crucial to close this research gap, especially from an economic and financial perspective, to better understand how the financial sector and therefore entire economies are reshaped by the current wave of digitization (Dapp, 2015).

To provide a first categorization and to establish a structure for the topic of interest, we seek to better understand and analyze this multidimensional problem. This approach is in line with the literature, and has proven its applicability as a first systemization of emerging phenomena (Haas, Blohm, \& Leimeister, 2014; Sabherwal \& King, 1995; Yaari, 1993). Accordingly, our research question is: What design parameters of bank-fintech cooperation can be distinguished?

Design parameters are characteristics that determine the form of a cooperation and allow one to dissect possible traits of existing cooperations. To answer the research question, we propose a taxonomy for bankfintech cooperation. We follow Nickerson, Varshney, and Muntermann's (2013) iterative approach, using both the literature and empirically verified knowledge. Real-world cases from a database consisting of 136 cooperations of banks and fintechs, and 12 expert interviews with bank and fintech executives as well as industry experts represent the empirical perspective. With our taxonomy, we seek to make two contributions: First, we aim to contribute to theory-building (Doty \& Glick, 1994; Iivari, 2007) by classifying dimensions of cooperation. Thus, the proposed taxonomy delivers a structured and systematic organization of the integration of external organizations (Glass \& Vessey, 1995). Further, our research focuses on developing a theory for analysis (type I) (Gregor 2006) that lays the foundation for further theory development in this domain. Second, our research addresses several opportunities for practitioners, describing typical characteristics to shape bank-fintech cooperation (e.g. possible cooperation models, integration structures). Further, by applying the proposed taxonomy to our case database, we introduce and discuss prevailing cooperation designs between banks and fintechs. Thus, our proposed taxonomy establishes fundamental parameters for the analysis of current cooperation as well as for the prediction of future cooperation developments (Glass \& Vessey, 1995).

The remainder of this paper is organized as follows: In Section 2, we lay the theoretical foundations for the proposed taxonomy and discuss existing theory in this domain. We then introduce the research methodology and describe the taxonomy development process. Hereafter, we present the resulting taxonomy and prevailing cooperation patterns. Finally, we discuss limitations and further research and conclude by highlighting the paper's theoretical and practical contributions.

\section{Foundations}

In this section, we introduce current digital transformation and its implications for the banking sector. Further, we address the relationship between the digital transformation and innovation as well as fintechs' roles in the banking sector. Finally, we discuss cross-organization cooperation as a promising solution to foster a bank's innovation capability.

\subsection{The Digital Transformation of the Banking Sector}

Digitalization is a pervasive phenomenon in the 21st century that has changed or disrupted many industries in the past few years (Benlian et al., 2014). Digital technologies enable new functionalities and open up 
promising business opportunities, changing perceptions of IT and its roles (Bharadwaj et al., 2013). Embedded computing power have turned products into smart and interconnected things, such as cars, phones, televisions, cameras, or bicycles (Yoo, 2010). Technological improvements are also reshaping and transforming key business operations, products, processes, organizational structures, and management theories (Matt, Hess, \& Benlian, 2015). Thus, entire value chains across organizational boundaries and business models are being reshaped and replaced by innovative solutions, which are enabled by disruptive technological improvements (Downes \& Nunes, 2013). These developments are based on digitizing - which is a technical process - and invoke digitalization, a sociotechnical process of "applying digitizing techniques to broader social and institutional contexts" (Tilson, Lyytinen, \& Sørensen, 2010, p. 749).

As one indicator among many, digitalization is also strongly affecting the banking industry and is changing the traditional branch system orientated sector (Dapp, 2014, 2015; Moutinho, Davies, Deng, Miguel Peris, \& Enrique Bigne Alcaniz, 1997). This also influences banks' capabilities to create stakeholder value (Hirt \& Willmott, 2014; Walters, 2014). Generally, digitalization provides several opportunities for banks, such as the enhancement of customer interactions, the improvement of management decisions, and the enabling of new value chains and business models (Hirt \& Willmott, 2014). Further, various threats emerge through digital transformation, such as winner-takes-all dynamics, modular and interchangeable business model blocks, and a lack of digital talent (Hirt \& Willmott, 2014). In addition, borderless global transactions, high transparency, and commoditized products lead to lower switching costs as well as lower market entry barriers (Hirt \& Willmott, 2014). However, in Europe, the majority (60\% to 80\%) of bank processes are still not digitized, and $90 \%$ of Europe's banks invest less than $0.5 \%$ of their total spending on digital initiatives (Olanrewaju, 2014). Yet, only 50\% of the interviewees in an expert paper confirmed that their banks have a strategic approach to replace old technologies (Skan et al., 2015), and only a few understand that the change needs to be instantaneous and in a fundamental manner (Ernst \& Young, 2011). Thus, banks must quickly adapt to the challenges of digital transformation, so as to become innovative, digital, and agile players - drivers in the field and successful in the market (Accenture, 2015; Ernst \& Young, 2011; Jaubert et al., 2014).

\subsection{Innovation, Innovation Sourcing, and Fintechs in the Banking Sector}

Many of the new opportunities enabled by digitalization are based on innovation, and change the nature of products and services (Yoo, Boland Jr, Lyytinen, \& Majchrzak, 2012). Innovation is "the generation, acceptance, and implementation of new ideas, processes, products or services" (Thompson, 1965, p. 2), and innovation management is crucial for organizations' success (e.g. Drucker, 1984; Schumpeter, 1942; Teece, 2010; Van de Ven, 1986). Nonetheless, many organizations - especially in the banking sector - fail to continuously change and innovate (Tushman \& Nadler, 1986). The target-oriented pursuit of innovation in practice has been a strategic asset and even a market entry barrier for potential competitors for centuries (Chesbrough, 2004). A company's innovation strategy comprises internal innovation (e.g. R\&D activities), and external innovation (e.g. acquisition and headhunting experts) (Cassiman \& Veugelers, 2006). Further, the creation of innovation depends on several internal and external factors (O'Riordan, 2013). In the past, organizations that invested the most in internal R\&D also earned the most profits (e.g. DuPont, Merck, IBM, GE and AT\&T, c.f. Chesbrough, 2004). However, a variety of newcomer organizations are strongly challenging industry leaders with little or no basic own research (e.g. Intel, Microsoft, Oracle, Uber, c.f. Chesbrough, 2004). These companies innovate based on other organizations' research activities and discoveries (Chesbrough, 2004). Thus, external sources of knowledge and innovation become highly relevant for business success (Chesbrough, 2004; Jaubert et al., 2014). Nowadays, in a digital world, remarkable innovations are closely linked to the rapidly evolving nature and the advanced market penetration of IT (Fichman, Dos Santos, \& Zhiqiang, 2014). The foundations of service innovation are rapid advancements coupled with widespread use of information and communication technologies (Brynjolfsson \& Hitt, 2000; Chen \& Tsou, 2006). 
In the banking sector, these technology-driven innovations are currently significantly propelled by fintechs. Fintechs are financial technology companies that bring technology solutions and new innovations to the financial sector, providing more effective financial products and services that are aligned to the digital era. These startup companies are agile and consist of dynamic teams with short development cycles and low internal bureaucracy, resulting in a very fast time-to-market and higher innovative capabilities compared to large incumbent firms (Ansari \& Krop, 2012; Christensen, 2013). In contrast, large and recently successful companies often focus on their current technology, avoid the risk of uncertainty and new approaches, and face a lack of creativity (O'Connell, 2011). To overcome these shortcomings, the literature suggests cooperation across company borders, and researchers have studied reasons and effects of cooperation in a wide variety of usage cases and methodologies (Teece, 1992).

\subsection{Cross-organizational Cooperation to Enhance Innovation Capabilities}

To support innovation, companies enter cooperations, bringing their expertise and benefitting from other companies' knowledge and technologies (Hippel, 2005; Nooteboom, 1999). Cooperating companies have realized that innovation is not a single-player activity, but an inter-firm exchange of information and resources (Becker \& Dietz, 2004). Hagedoorn (1993) found the urge for technology and market knowledge to be a significant reason for companies to cooperate in order to innovate. Ultimately, organizations cooperate in order to improve their competitive position and performance (e.g. Ernst, Halevy, Monier, \& Sarrazin, 2001; Hitt, Dacin, Levitas, Arregle, \& Borza, 2000; Jarillo, 1988; Teece, 1987).

Since companies began to cooperate, there have been questions about different approaches, their implications, and influences on innovation capability. Studies of cross-organizational cooperation suggest that strategic alliances, merger and acquisitions, and incubation are innovation-enhancing forms of cooperation (Bergek \& Norrman, 2008; Man \& Duysters, 2005). Strategic alliances positively affect innovation if the involved parties' managers are equipped to manage alliances (e.g. Anand \& Khanna, 2000; Powell, Koput, \& Smith-Doerr, 1996; Takeishi, 2001), if the involved parties share similar or overlapping knowledge (e.g. Chan, Kensinger, Keown, \& Martin, 1997; Koh \& Venkatraman, 1991; Lane \& Lubatkin, 1998; Mowery, Oxley, \& Silverman, 1996), or if the form of cooperation is intense (e.g. Dyer, 1996, 2000; Hagedoorn \& Schakenraad, 1994). Compared to research into strategic alliances, there has been less extensive research into the relationships between mergers and acquisitions or incubation with innovation. The acquisition of knowledge is found to positively impact on post-merger performance and innovation effectiveness (Ahuja \& Katila, 2001). Bergek and Norrman (2008) reviewed different components of the existing incubation literature with a focus on incubation selection strategies, and found a positive influence of incubation on a company's innovation capability (Hackett \& Dilts, 2004).

Previous research has addressed and answered various research questions in the realm of cooperation, innovation, and their coherence, and has therefore made excellent contributions to understanding. Yet, bankfintech cooperation differs from the existing theory, since two presumably unsymmetrical aims and market positions collide. For banks and fintechs, the motivation to enter into a cooperation is sound, for many reasons. Banks seek to profit from the development of new customer segments, products, and services, expanding into new markets, developing new capabilities, and accessing new technologies (Economist Intelligence Unit, 2015). In return, fintechs look for the financial resources, infrastructures, access to customers, and security reputation. However, there has been very little research into this new phenomenon in the financial markets (Tornjanski et al., 2015), while recent developments in the banking sector suggest the need to closely look at this specific application of cooperation. The situation in the banking sector differs from former constellations and poses new challenges. The incumbents in the financial sector somehow depend on fintechs, and fintechs don't fear established institutions, but carefully choose their cooperation partners, often working with more than one. Further, fintechs' innovativeness becomes a driver of customer satisfaction and challenges as well as changes the business models in the banking sector. Alongside this challenge, we place the corresponding design parameters at the center of our paper, addressing how banks 
and fintechs can work together to increase banks' innovativeness. To lay the foundations and better understand this phenomenon, taxonomy development has proven its systemization efficacy numerous times across several industries (Fiedler, Grover, \& Teng, 1996; Sabherwal \& King, 1995; Williams, Chatterjee, \& Rossi, 2008; Yaari, 1993).

\section{Research Method}

A taxonomy provides a set of unifying constructs, resulting in a structure and a systematic organization of an examined environment (Glass \& Vessey, 1995). Thus, a taxonomy is "useful in discussion, research, and pedagogy" (Miller \& Roth, 1994, p. 286) in order to organize knowledge (Wand, Monarchi, Parsons, \& Woo, 1995) and to increase understanding (Gregor, 2006). However, taxonomies not only systematically describe a research area's current developments, relationships, and dependencies, but also lay the foundation for higher-order theory in an examined field (Glass \& Vessey, 1995), such as theory for explaining and predicting, or theory for design and action (Gregor, 2006). We apply Nickerson et al.'s (2013) taxonomy development approach, since it goes beyond previous approaches (e.g. Bailey, 1984). This method integrates conceptual and empirical perspectives into one comprehensive method that fosters the iterative usage of both paradigms and has been successfully applied multiple times by several researchers (Glaser \& Bezzenberger, 2015; Haas et al., 2014; Jöhnk, Röglinger, Thimmel, \& Urbach, 2017; Püschel, Röglinger, \& Schlott, 2016).

According to Nickerson et al. (2013), taxonomy development encompasses seven steps. Steps 1 and 2 set the research field and determine the taxonomy's boundaries. Steps 3 to 7 are conducted iteratively, to define and validate the taxonomy's dimensions and characteristics. In step 1, a meta-characteristic is determined to serve as the base for all dimensions and characteristics introduced in the taxonomy development process. Each taxonomy characteristic logically follows the meta-characteristic. This initial step guides the research process and helps researchers to avoid the examination of unrelated characteristics. Thus, the choice of the meta-characteristic is very important, and needs to be elaborated thoroughly and with care. Step 2 embodies the determination of ending conditions, which terminate the iterative development process. The ending conditions, also seen as a form of Rich's (1992) guidelines for a classification process, are strongly relevant and determine the method's scope and outcome. They determine the quality standard and validity taxonomies must fulfill for acceptance as a temporarily finalized artifact. For steps 3 to 7, Nickerson et al. (2013) distinguish between a conceptual-to-empirical (C2E) and an empirical-to-conceptual (E2C) approach. In the $\mathrm{C} 2 \mathrm{E}$ approach, the researcher starts with a conceptual or theoretical foundation and derives the dimension's structure via deduction, until it is satisfactorily complete (Bailey, 1994). In the E2C approach, the researcher starts with data and derives the dimension's structure using analysis of the actual data, detecting similarities or distinctions (Bailey, 1994). For each iteration, the researcher decides if either the first or the latter approach is applied and helpful to further develop the taxonomy (step 3). The empirical component of the development method generally contributes to verify, validate, and revise existing dimensions and characteristics as well as to identify the necessity of additional classification criteria. The outcome of step 3 influences how steps 4, 5, and 6 are shaped. In step 7, the latest taxonomy is compared to the determined ending conditions, and a decision is made about whether another iteration will be conducted. Owing to fast-changing targets, the design science literature describes the search for an optimal solution as "intractable for realistic information systems problems" (Hevner, March, Park, \& Ram, 2004, p. 88). Thus, our proposed taxonomy represents an initial structure and a systematic overview of the emerging research field of bank-fintech cooperation.

\section{The Taxonomy Development Process}

In our taxonomy development process, we built on existing theoretical knowledge and available expertise to consider both the conceptual and the empirical perspectives (Nickerson et al., 2013). For the conceptual 
perspective, we dissected the theoretical background of cooperation patterns and reviewed related literature streams. In this procedure, two researchers independently identified and analyzed relevant papers and condensed their insights in several discussions meetings. For the empirical perspective, we included publicly available data of cooperation cases between banks and fintechs (secondary data) and conducted interviews with banking executives, fintech representatives, and industry experts (primary data). An overview of the applied research steps appears in Table 1. We explain the associated iteration cycles in greater detail in the following sections. Further, in Appendix II, we provide an overview of the evolving taxonomy.

\begin{tabular}{|c|c|c|}
\hline$\frac{1}{\frac{1}{2}}$ & \multicolumn{2}{|c|}{$\begin{array}{l}\text { Determine the meta-characteristic } \\
\text { Based on the identified lack of research and according to our research question, we defined the meta- } \\
\text { characteristic as follows: Design parameters of bank-fintech cooperations in the context of banks, } \\
\text { innovation capability enhancement }\end{array}$} \\
\hline$\overbrace{\frac{1}{2}}^{N}$ & \multicolumn{2}{|c|}{$\begin{array}{l}\text { Determine ending conditions } \\
\text { We chose well-established and widely recognized ending conditions and clustered them into objective and } \\
\text { subjective criteria (Nickerson et al., 2013). A detailed overview appears in Table } 2 .\end{array}$} \\
\hline$\frac{2}{\frac{2}{\pi}}$ & \multicolumn{2}{|c|}{$\begin{array}{l}\text { Choose between a C2E and an E2C approach } \\
\text { Based on available real-world cooperation cases, interview partners, and identified literature streams, we } \\
\text { chose a C2E or an E2C approach. }\end{array}$} \\
\hline & Conceptual-to-empirical (C2E) & $2 \mathrm{C})$ \\
\hline & $\begin{array}{l}\text { 4c. Conceptualize (new) characteristics and } \\
\text { dimensions of objects } \\
\text { We analyzed literature from various fields, such as } \\
\text { cross-organizational cooperation, innovation, and } \\
\text { value creation in order to conceptualize } \\
\text { characteristics and dimensions. }\end{array}$ & $\begin{array}{l}\text { We searched for bank and fintech cooperations cases } \\
\text { (secondary data) and utilized insights about cases } \\
\text { from the expert interviews (primary data). }\end{array}$ \\
\hline$\frac{n}{\frac{\pi}{2}}$ & $\begin{array}{l}\text { 5c. Examine objects for these characteristics and } \\
\text { dimensions } \\
\text { We evaluated the appropriateness and correctness of } \\
\text { the proposed characteristics and dimensions by } \\
\text { examining bank-fintech cooperation cases as well as } \\
\text { via insights from the expert interviews. }\end{array}$ & $\begin{array}{l}\text { 5e. Identify shared characteristics and group } \\
\text { objects } \\
\text { We examined the identified objects, clustered them, } \\
\text { and derived shared characteristics. We also analyzed } \\
\text { literature relating to the characteristics to obtain a } \\
\text { more objective and comprehensive understanding of } \\
\text { the phenomena. }\end{array}$ \\
\hline$\frac{0}{\frac{\pi}{2}}$ & $\begin{array}{l}\text { revise the taxonomy } \\
\text { modified the current taxonomy. }\end{array}$ & $\begin{array}{l}\text { 6e. Group characteristics into dimensions to } \\
\text { create or revise the taxonomy } \\
\text { We grouped the identified characteristics into } \\
\text { dimensions and, if required, revised the current } \\
\text { taxonomy. }\end{array}$ \\
\hline$\frac{1}{\frac{\pi}{2}}$ & \multicolumn{2}{|c|}{$\begin{array}{l}\text { Examine ending conditions } \\
\text { After each development iteration, we evaluated whether the ending conditions were met. For instance, we } \\
\text { assessed whether new characteristics and/or dimensions were added or if the number of characteristics and } \\
\text { dimensions allow the taxonomy to be meaningful (concise). }\end{array}$} \\
\hline
\end{tabular}

Table 1. Applied Taxonomy Development Method of Nickerson et al. (2013)

\subsection{Steps 1 and 2}

The core activities in the first two steps comprise the definition of the meta-characteristic and the determination of the ending conditions for the taxonomy development process. Hence we focused on proposing an initial overview of design parameters of bank and fintech cooperations and defined the metacharacteristic as follows: Design parameters of bank-fintech cooperations in the context of banks' innovation capability enhancement. Following Nickerson et al.'s (2013) approach, the ending conditions were clustered into objective and subjective termination criteria (Table 2). The objective ending conditions focus on the formal correctness of the taxonomy and the development process, while the subjective ending conditions assure the proposed taxonomy's meaningfulness and usefulness (Nickerson et al., 2013). 


\begin{tabular}{l} 
Objective ending conditions \\
\hline - A representative sample of bank-fintech cooperations (objects) is examined \\
- Every characteristic of each dimension classifies at least one object \\
- No of the dimensions is duplicated \\
- None of the characteristics in one dimension are duplicated \\
- No additional dimension or characteristic is added in the last iteration \\
- No objects, dimensions, or characteristics are merged or split in the last \\
iteration
\end{tabular}

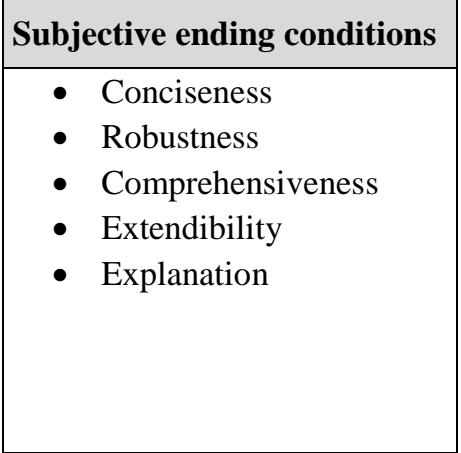

Table 2. Objective and Subjective Ending Conditions (based on Nickerson et al. 2013)

\subsection{Steps 3 to 7}

During the taxonomy development process, we reciprocally conducted four C2E and 13 E2C iterations. Thus, we not only relied on secondary data, but obtained an impartial and multifaceted perspective. In step 3 of each development cycle, we decided for a $\mathrm{C} 2 \mathrm{E}$ or an E2C approach based on available cases and identified literature streams.

We based each of the C2E taxonomy development iterations on a specific research stream, such as crossorganizational cooperation, innovation, and organization architecture, in order to conceptualize dimensions and characteristics (step 4c). Subsequently, we verified the appropriateness and correctness of the proposed dimensions and characteristics by examining bank and fintech cooperation cases as well as via insights from the expert interviews (step 5c). Based on the outcome of this examination, we conducted necessary adaptations to the taxonomy (step 6c). In the E2C iterations, either samples of the cooperation cases or expert interviews served as the starting point (step 4e). We then analyzed the identified objects and derived common characteristics in line with the meta-characteristic (step 5e). We also studied the literature related to the identified dimensions and characteristics, to strengthen the observed phenomena and to ensure maximum objectivity. Afterwards, we grouped the characteristics into dimensions and revised the current taxonomy (step 6e). At the end of each iteration, we measured the fulfillment of our ending conditions and evaluated whether or not an additional development cycle was required (step 7).

During the 17th development cycle, we did not observe the need to change or adapt the current taxonomy. Further, none of the dimensions and combinations of the characteristics were duplicated, and every characteristic classified at least one object. The resulting taxonomy has 13 dimensions and is meaningful and therefore concise (Miller, 1956). Since the characteristics provide sufficient differentiation between the objects, we considered the taxonomy to be robust. Moreover, we identified and classified a large proportion of bank and fintech cooperations, and indicated that the proposed taxonomy is comprehensive. The taxonomy is extendible, since it can easily be adapted by new characteristics and dimensions. Also, the taxonomy suits the intended use and describes the cooperation of banks and fintechs with an appropriate level of detail (explanatory). Thus, after the 17th iteration, our taxonomy met all ending conditions, and we conducted no additional development cycle.

Overall, we gathered information about 136 bank-fintech cooperation cases from a database (Bajorat, 2015, cf., Appendix I). Further, we enriched the data by publicly available information on the cooperations, such as published newspapers, company white papers, and company websites. We also conducted expert interviews with 12 bank and fintech executives as well as industry experts (Table 3) in a semi-structured manner, with designed questions and interview guidelines to assure comparability and to preserve explorativeness (Yin, 2013). We primarily framed the interviews around a greenfield approach, since the experts unbiasedly stated their ideas towards a categorization model of bank-fintech cooperation. This initial step was crucial, since it allowed us to gain unrestrained interviewee insights and thoughts. Part 2 of the 
interviews consisted of a discussion of the current taxonomy and the classification of at least one bankfintech cooperation the interviewee was involved in. This part of the interview allowed us to evaluate the proposed taxonomy based on real-world experience (Schultze \& Avital, 2011). Every interview was conducted via phone or personally, lasted between 45 and 70 minutes, and was recorded. The recorded interviews were systematically and independently analyzed by two researchers (Saldaña, 2009).

\begin{tabular}{|l|l|l|l|}
\hline ID & Interviewee's position & Relationship to bank-fintech interaction & Firm \\
\hline 1 & Executive or C-level & Involved in the strategic alignment of bank-fintech cooperation & Bank \\
\hline 2 & Executive or C-level & M\&A in the banking sector; formerly C-level central bank & Bank \\
\hline 3 & Executive or C-level & Involved in bank-fintech cooperation & Bank \\
\hline 4 & Middle management & Involved in bank-fintech cooperation & Bank \\
\hline 5 & Middle management & Involved in bank-fintech cooperation & Bank \\
\hline 6 & Middle management & Involved in bank-fintech cooperation & Bank \\
\hline 7 & Middle management & Involved in bank-fintech cooperation & Fintech \\
\hline 8 & Middle management & Involved in bank-fintech cooperation & Fintech \\
\hline 9 & Middle management & Involved in bank-fintech cooperation & Fintech \\
\hline 10 & Middle management & Involved in bank-fintech cooperation & Fintech \\
\hline 11 & Advisor & Involved in regulatory requirements of bank-fintech cooperations & Regulator \\
\hline 12 & Senior Project Manager & Involved in the structuring of bank-fintech cooperation project & Consulting \\
\hline
\end{tabular}

Table 3. Overview of interviewees

\section{Results}

The taxonomy development process has two results. First, we describe the final taxonomy and the respective dimensions and characteristics. Second, we apply the taxonomy to our dataset and present the prevailing cooperation patterns.

\subsection{A Taxonomy for Bank-Fintech Cooperation}

The final taxonomy consists of 13 relevant dimensions, encompassing 106 characteristics (Table 4). We derived the dimensions and characteristics according to the meta-characteristic to describe and explain the bank-fintech cooperation to foster innovation. 


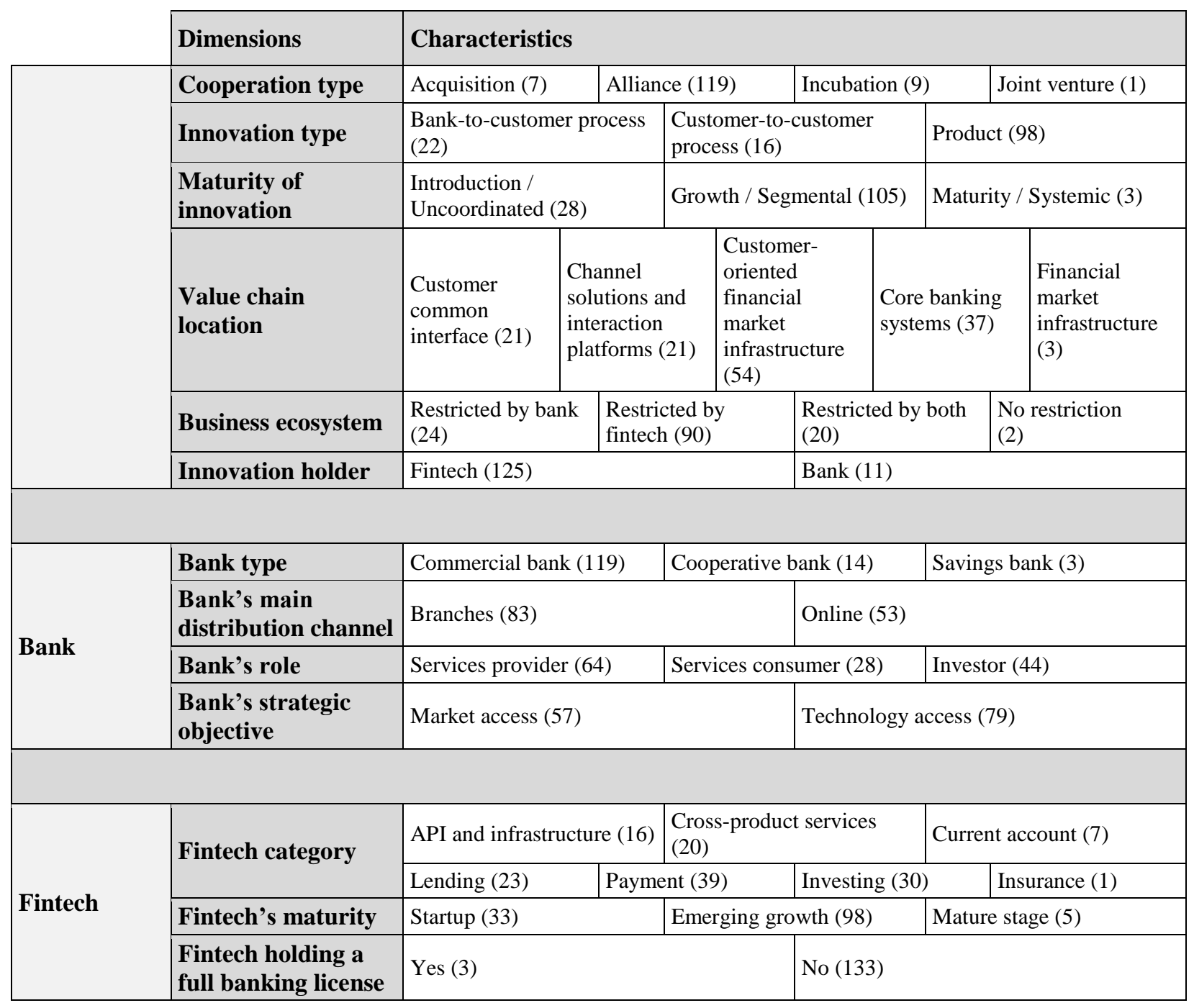

Table 4. A Taxonomy for Bank-Fintech Cooperation

The derived dimensions either characterize the cooperation, or the involved participants, bank and fintech. In the following sections, we outline the inclusion and the structuring of each dimension into characteristics.

\section{Cooperation Type}

Bank-fintech cooperations differ in their legal connections (Seo \& Hill, 2005). In line with the literature and the conducted interviews, we derived the characteristics acquisition, alliance, incubation, and joint venture (e.g. Bøllingtoft \& Ulhøi, 2005; Seo \& Hill, 2005). An alliance is a contractual arrangement between companies to share resources and knowledge to achieve shared goals (e.g. bank and fintech cooperate in a beneficial manner, Teece, 1992). An acquisition is a corporate action in which the acquiring company buys a majority of the target company and integrates it into its existing structures (e.g. the bank determines the strategy and decisions of the fintech company, Seo \& Hill, 2005). Incubation is the fostering of early-stage companies through financial, managerial, or other assistance (e.g. the fintechs are founded within the realm of the bank) (Bøllingtoft \& Ulhøi, 2005; Kogut, 1988; Teece, 1992). In a joint venture, resources are pooled in a specifically independent but shared entity, while its risks and responsibilities are carried by the participating organizations (e.g. a bank and a fintech company jointly found a new company) (Kogut, 1988). The database and expert interviews supported the classification of these four characteristics. 


\section{Innovation Type}

The existing research distinguishes between product and process innovation (Utterback \& Abernathy, 1975). First, a "product innovation is the introduction of a good or service that is new or significantly improved regarding its characteristics or intended uses" (OECD Oslo Manual, 2005, p. 48; Porter, 2001). Second, a "process innovation is the implementation of a new or significantly improved production or delivery method" (OECD Oslo Manual, 2005, p. 49; Porter, 2001). Because the interviews revealed that innovations primarily focus on specific processes, we further divided the process innovation into customerto-customer and bank-to-customer (B2C) process innovation. Since the analyzed cooperation cases revealed similar characteristics, this segmentation is a better description of the innovation type.

\section{Maturity of Innovation}

While examining the cooperation cases, notably, the related innovations show different maturity stages. The literature on product lifecycle models suggests representing different maturities via multistep models. Thus, the product lifecycle is represented in a four-step model: the introduction of a new product into its potential market, growth of sales, market share, and profitability, maturity with stabilizing sales and market shares, and decline with sales and shares dropping and the product no longer relevant or useful (Day, 1981). Since specifically innovative products are in the focus of the research, the decline stage was neither represented in the analyzed sample nor suggested by the experts, and was therefore not included in the taxonomy. Comparable to the product lifecycle, process maturity has three stages. First, the processes follow an uncoordinated approach and are able to easily respond to environmental change (Utterback \& Abernathy, 1975). The second stage, called segmental, is characterized by a higher process integration and higher automation in some segments (Utterback \& Abernathy, 1975). Third, the systemic stage describes highly developed and integrated processes with resistance to change (Utterback \& Abernathy, 1975). In the innovation maturity dimension, we included the characteristics Introduction / Uncoordinated, Growth / Segmental, and Maturity / Systemic to address both product and process innovations.

\section{Value Chain Location}

The analysis of the expert interviews revealed that bank-fintech cooperations focus on specific parts of the value chain. This is also in line with the aims of fintechs, since they seek to address specific customer needs rather than an exhaustive solution. This is also confirmed by the evaluated dataset. For the proposed taxonomy, we follow Alt and Puschmann (2012), dividing the banking industry value chain into five sections: customer common interface, channel solutions (CS) and interaction platforms (IP), customeroriented financial market infrastructure (FMI), core banking systems, and financial market infrastructure. The customer common interface is an integrated financial cockpit, within which customers are able to manage and plan their financial profiles, for instance plan liquidity, accumulation of capital (Alt \& Puschmann, 2012). The CS and IP facilitate bank-customer interaction (e.g. online banking, mobile banking) (Alt \& Puschmann, 2012). The customer-oriented FMI relates to platforms or marketplaces that provide products and services directed towards customers. The core banking systems are the back-end systems that process daily banking transactions and post updates to accounts and other financial records. Finally, financial market infrastructures are inter-bank processes and capabilities such as stock exchange, clearing organization, and payment organization (Alt \& Puschmann, 2012). The value chain location is included to describe the aim of the fintech's innovation.

\section{Business Ecosystem}

Most interviewed experts stated that innovations in the digital era support or even constitute the existence of business ecosystems. Business ecosystems are defined as economic communities that involve several companies working cooperatively and comparatively to gain advantages through their symbiotic relationships (Moore, 1993). An ecosystem's members - including suppliers, lead producers, competitors, and other stakeholders - co-evolve their capabilities and roles, and align themselves with the other players in the ecosystem (Moore, 1993). The direction is set by one or more central companies. Banks and fintechs 
seek to build an ecosystem for their customers. The cases in the database show that the cooperation is usually directed towards making the innovation accessible for a certain customer target group. Thus, the innovation's use is restricted either through membership (account) in the fintech (restricted by fintech), in the bank (restricted by bank), or restricted by both. Only in some cases is the access not restricted. We divide all four possibilities in order to categorize which party is the restricting element in the cooperation, thus placing itself in the center of the ecosystem.

\section{Innovation Holder}

A specific interest with a cooperation is how the involved parties proceed with the innovation and the corresponding ownership. In a cooperation, the innovation can either remain with the fintech, or it can be fully integrated by the bank. The database revealed a distinction concerning where the innovation is located in a cooperation - in the bank or in the fintech. The interviewed experts also noted the distinction and recommended including it as a characteristic in the taxonomy.

\section{Bank Type}

The next relevant characteristics are based on literature on banking systems and encompass three groups of banks: commercial banks, cooperative banks, and savings banks (Schmidt \& Krahnen, 2004). The commercial banks are privately owned and are more profit-oriented than the other two groups (Behr \& Schmidt, 2015). Although cooperative banks have characteristics of commercial banks, their internal structure differs significantly, since the bank is owned by its members (Behr \& Schmidt, 2015). Saving banks are characterized by a specific business focus on savings and savings mobilization as well as a focus on local markets (Behr \& Schmidt, 2015). While analyzing the sample objects in-depth, this categorization was confirmed.

\section{Bank's Main Distribution Channel}

Further, for the cooperation, the main bank's distribution channel plays a key role, since it influences the ability to establish connection points with the fintech and provides insights into customer relationships. While branch-oriented banks often focus on the physical interaction with their customers, this complicates the integration of innovative online fintech solutions. Thus, in line with the expert interviews, we include the bank's main distribution channel into the taxonomy and distinguish between online distribution and branch orientation.

\section{Bank's Role}

The experts stated that, similar to a bank's strategic objective, banks' roles differ in cooperations. Banks either act as a service provider, enabling fintechs' products by providing banking services, or as service consumer, using the fintech's innovation to improve own products or processes. Further, we observed that some banks act as an investor and hold shares in fintech companies. Since the interviewed experts ascertained the same phenomenon, the three characteristics were endorsed and included.

\section{Bank's Strategic Objective}

Another important aspect of bank-fintech cooperations is the bank's strategic objective. Previous research suggests predominately two reasons why banks enter interfirm cooperations. First, motives relate to characteristics of technological development. This entails the leverage of synergies (cf. e.g. Mariti \& Smiley, 1983; Porter \& Fuller, 1986), reduction and sharing of uncertainty (cf. e.g. Berg, Duncan, \& Friedman, 1982; Ohmae, 2002) or technology development costs (cf. e.g. Ohmae, 2002). This can be either the capturing of a partner's tacit knowledge of technology, technology transfer, technology application, and technological leapfrogging (cf. e.g. Harrigan, 1985; Mariti \& Smiley, 1983; Pisano, Shan, \& Teece, 1988). Second, motives relate to market access and the search for opportunities. These can be the monitoring of environmental changes and opportunities (cf. e.g. Mariotti \& Ricotta, 1986), internationalization and globalization (cf. e.g. Ohmae, 2002), as well as new products and markets, market entry, branding, and 
product range expansion (cf. e.g. Hladik, 1985, 1988). Thus, we distinguished between market access and technology access.

\section{Fintech Category}

Our examination of the sample cases revealed various categories of fintechs. These categories are based on the list of regular financial products or services. These are lending, investing, insurance, payment, current account, cross-product service. Further, fintechs also provide API and infrastructure as digital interfaces for other companies and customers. Fintechs in the category lending work on innovative solutions, where customers can lend money via a platform directly from other customers or financial institutions (e.g. crowdfunding, instant lending). Fintechs in the category investing focus on delivering innovative investment solutions to improve the customers' investment opportunities (e.g. robo-advisory, investment intermediation). Fintechs in the category insurance market novel insurance models to customers (e.g. insurance solutions and services). Fintechs in the category payment develop payment solutions (e.g. mobile payment, crypto-currency). Fintechs in the category current account supply innovation that focuses on account management and invoicing solutions (e.g. integrated digital accounting solutions). Fintechs in the category cross-product service develop applications that support customers' interactions with their contracting parties, such as banks and insurance companies (e.g. video identification, bank switching). Fintechs in the category API and infrastructure work on digital interfaces that allow other companies to provide solutions for customers or connect with other companies (e.g. integrated warehousing). Since fintechs search for innovation potential to provide untapped value for customers, the categorization is not conclusive at this point. Our initial categorization based on regular financial products and services can only serve as a starting point. A validation through the literature is not possible at this point. Nonetheless, the expert interviewees follow the suggested itemization, and we classified all cases from the database.

\section{Fintech's Maturity}

Research distinguishes four stages of an organizational lifecycle. The startup stage, with the development of a business plan and entry into the market place, the emerging growth stage, with expansion efforts, the mature stage, with a slow growth rate, and the decline stage with movement from the mature stage to the transition stage (Jawahar \& McLaughlin, 2001). According to the interviewed experts, a fintech's maturity is important, for two reasons. First, such maturity indicates how well the organization and internal processes are established in the market. Second, such maturity relates closely to the bargaining power in a cooperation. Fintechs are startup companies in the early stages of the lifecycle model. Since the decline stage did not occur in the case sample, nor the experts suggested it, we did not include this characteristic in the taxonomy.

\section{Fintech Holding a Full Bank License}

While the taxonomy development process revealed that most fintechs don't have a full banking license, a banking license plays a key role in bank-fintech cooperation, since it defines a fintech's abilities to offer and process financial products without a bank. To offer banking products and services in the - regulated banking industry, a banking license is mandatory. Thus, we added this dimension with the characteristics yes and no to the taxonomy.

\subsection{Bank-Fintech Cooperation Patterns}

In this section, we present the results of the taxonomy application to the used dataset and discuss the peculiarities of our taxonomy characteristics. We also conduct a k-nearest neighbor cluster analysis and introduce prevailing bank-fintech cooperation patterns.

\section{Application of the Bank-Fintech Cooperation Taxonomy}

In the taxonomy development, we dissected and classified 136 real-world cooperations cases. Our dataset encompasses European and U.S. banks as well as international fintechs. Overall, the most cooperations are alliances $(78 \%)$ and focus on product innovation $(72 \%)$ in the customer-oriented financial market infrastructure (39\%). Acquisition (5\%) and incubation (9\%) play only minor roles, while joint ventures are 
only represented in one case (1\%) in our sample. In most cases $(91 \%)$, the innovation remains with the fintech. Focusing on the innovation and fintech maturity, both lay in the earlier lifecycle stages, with $97 \%$ of the innovations in pre-maturity stages, and $96 \%$ of the fintechs in the startup or growth stages. In more than $66 \%$ of the cooperations, the fintech builds a business ecosystem, and banks try to enter this restricted ecosystem. The banks in our dataset are primarily commercial banks $(87 \%)$ with a branch-oriented distribution network $(61 \%)$ and act as service provider $47 \%$ by for instance providing account management services or the bank license for the cooperation. However, it is conspicuous that $64 \%$ of the classified U.S. banks acted as investors, while only $24 \%$ of the European banks provided investment support. In general, the banks primarily seek to get access to the innovative technologies offered by fintechs. There are various categories of fintechs. Most are located in payment (28\%) and investing (22\%). The fintech categories lending (16\%), cross-product services (14\%), API and infrastructure (11\%), current accounts, (5\%) and insurance (1\%) were not predominantly represented in our dataset. It is also apparent that only three (2\%) of 100 fintechs are listed as a regulated financial institution with a banking license.

\section{Prevailing Bank-Fintech Cooperation Patterns}

To better understand and identify prevailing bank-fintech cooperation patterns, we conducted a cluster analysis. The results illustrate typical combinations, dominance, and retention of categories in the database. For reasons of clarity and comprehensibility, we restricted the number of clusters to six. We utilized the simple-K-means algorithm (distance function: Manhattan distance; initialization method: Farthest first; number of clusters: 6) in our cluster analysis. We summarized the results of the cluster analysis in Table 5 and hereinafter, we illustrate each of the identified clusters.

\begin{tabular}{|c|c|c|c|}
\hline & Cluster $1(38 \%)$ & Cluster $2(6 \%)$ & Cluster $3(3 \%)$ \\
\hline \begin{tabular}{|l|} 
Cooperation type \\
Innovation type \\
Maturity of innovation \\
Value chain location \\
Business ecosystem \\
Innovation holder \\
Bank type \\
Bank's main distribution channel \\
Bank's role \\
Bank's strategic objective \\
Fintech category \\
Fintech's maturity \\
Fintech holding a full banking \\
license
\end{tabular} & $\begin{array}{l}\text { Alliance } 90 \% \\
\text { Product } 75 \% \\
\text { Growth } 88 \% \\
\text { Core banking systems } 38 \% \\
\text { Restricted by fintech } 80 \% \\
\text { Fintech } 96 \% \\
\text { Commercial bank } 92 \% \\
\text { Branches } 94 \% \\
\text { Investor } 61 \% \\
\text { Technology } 86 \% \\
\text { Payment } 48 \% \\
\text { Growth } 88 \% \\
\text { No } 100 \%\end{array}$ & $\begin{array}{l}\text { Acquisition } 75 \% \\
\text { Product } 100 \% \\
\text { Introduction } 62 \% \\
\text { CS and IP 50\% } \\
\text { Restricted by bank } 75 \% \\
\text { Bank } 100 \% \\
\text { Commercial bank } 87 \% \\
\text { Branches } 100 \% \\
\text { Services Provider 62\% } \\
\text { Technology 75\% } \\
\text { Payment 50\% } \\
\text { Growth 75\% } \\
\text { No } 87 \%\end{array}$ & $\begin{array}{l}\text { Alliance } 100 \% \\
\text { B2C process } 100 \% \\
\text { Introduction } 75 \% \\
\text { Core banking systems } 75 \% \\
\text { Restricted by bank } 50 \% \\
\text { Fintech } 75 \% \\
\text { Commercial bank } 100 \% \\
\text { Online } 75 \% \\
\text { Services Provider } 75 \% \\
\text { Market } 50 \% \\
\text { Lending } 75 \% \\
\text { Growth } 75 \% \\
\text { No } 100 \%\end{array}$ \\
\hline & Cluster $4(33 \%)$ & Cluster $5(\mathbf{1 0 \%})$ & Cluster $6(10 \%)$ \\
\hline $\begin{array}{l}\text { Cooperation type } \\
\text { Innovation type } \\
\text { Maturity of innovation } \\
\text { Value chain location } \\
\text { Business ecosystem } \\
\text { Innovation holder } \\
\text { Bank type } \\
\text { Bank's main distribution channel } \\
\text { Bank's role } \\
\text { Bank's strategic objective } \\
\text { Fintech category } \\
\text { Fintech's maturity } \\
\text { Fintech holding a full banking } \\
\text { license }\end{array}$ & $\begin{array}{l}\text { Alliance } 95 \% \\
\text { Product } 86 \% \\
\text { Growth } 93 \% \\
\text { Customer-oriented FMI } 80 \% \\
\text { Restricted by fintech } 68 \% \\
\text { Fintech } 100 \% \\
\text { Commercial bank } 84 \% \\
\text { Online } 84 \% \\
\text { Services Provider 93\% } \\
\text { Market 91\% } \\
\text { Investing 60\% } \\
\text { Growth } 73 \% \\
\text { No } 97 \%\end{array}$ & $\begin{array}{l}\text { Alliance } 84 \% \\
\text { B2C process } 100 \% \\
\text { Growth } 92 \% \\
\text { Core banking systems } 46 \% \\
\text { Restricted by bank } 61 \% \\
\text { Fintech } 100 \% \\
\text { Commercial bank } 69 \% \\
\text { Online } 61 \% \\
\text { Services Consumer } 92 \% \\
\text { Technology } 100 \% \\
\text { Cross-product services } 100 \% \\
\text { Growth } 69 \% \\
\text { No } 100 \%\end{array}$ & $\begin{array}{l}\text { Alliance } 100 \% \\
\text { Product } 85 \% \\
\text { Introduction } 92 \% \\
\text { CS and IP 57\% } \\
\text { Restricted by fintech } 85 \% \\
\text { Fintech } 100 \% \\
\text { Commercial bank } 92 \% \\
\text { Branches 92\% } \\
\text { Investor 64\% } \\
\text { Technology } 64 \% \\
\text { Lending 28\% } \\
\text { Introduction } 92 \% \\
\text { No 92\% }\end{array}$ \\
\hline
\end{tabular}

Table 5. The Cluster Analysis Results 
Cluster 1: Invest in fintechs to form an alliance and access the fintech's ecosystem

Cluster 1 represents the largest group of the cooperation cases. It encompasses cooperations in which primarily branch-oriented banks invest in fintechs so as to access fintech-centered ecosystems. The value chain location and the fintech category are unclear for this cluster.

Cluster 2: Acquire and integrate channel solutions and interaction platform innovation

The prevailing pattern in cluster 2 can be illustrated as cooperation between branch-oriented banks seeking CS and IP technologies. The banks in this cluster acquire a fintech, restrict the ecosystem, and integrate the innovation to become its holder. The proportion of fintechs holding a bank license is the highest of all clusters.

\section{Cluster 3: Innovate lending core banking systems to optimize bank-to-customer processes}

This cluster is the smallest and represents only $3 \%$ of the analyzed cooperations. Cooperations in this cluster seek to innovating commercial banks in the lending field's core banking systems, to optimize bank-tocustomer processes.

\section{Cluster 4: Access investment markets by providing banking services to fintechs}

The second-largest cluster comprises banks cooperating with fintechs to access new investment innovations. The banks act as services providers and seek to access the market share of the fintech-restricted ecosystem.

\section{Cluster 5: Cross-product services to innovate bank-to-customer processes in bank ecosystems}

In cluster 5, the prevailing pattern consists of banks building alliances with fintechs that offer cross-product services. The main focus in this cluster is novel technological solutions for bank-to-customer processes, and the bank contributes as a service consumer. Although the innovation remains with the fintech, the bank restricts the ecosystem.

\section{Cluster 6: Early-stage cooperation to access technology}

In cluster 6, banks cooperate with early-stage fintechs that focus on early-stage innovations. The ecosystem is restricted by the fintech, and the innovation remains with the fintech. The bank seeks to access the innovation technology, while the category of fintech is unclear.

\section{Conclusion and Outlook}

In this research paper, we discussed the far-reaching implications of digital transformation in the financial sector (Mols, 1998; Tilden, 1996). The global financial sector is undergoing major changes as banks face various internal problems, leading to a lack of innovation capability (Tornjanski et al., 2015), and fintechs are picking up technology-enabled opportunities to push into the market (Dapp, 2015). To overcome these challenges, cross-organizational cooperation has proven its applicability and its positive effects. Thus, cooperation with fintechs is becoming an increasingly prominent option for banks, to foster innovation (Economist Intelligence Unit, 2015). Based on previous research, we bridge the aforementioned research gap by applying a taxonomy development method that combines a conceptual-to-empirical approach and an empirical-to-conceptual one (Nickerson et al., 2013). Thus, we propose a taxonomy to establish an overview of dimensions and design parameters of bank-fintech cooperation that seeks to foster banks' innovation capabilities. For this purpose, we collected data of 136 bank-fintech cooperations, and conducted 12 expert interviews with bank and fintech executives as well as industry experts.

Before concluding with recommendations and emphasizing our contributions to both research and practice, we acknowledge some limitations, highlighting promising starting points for future research. First, the resulting taxonomy is influenced by the applied database and the iterations sequence in the development process, a generally valid drawback. Applying a divergent iterations sequence in the taxonomy development process may influence the outcome. Second, the classification of each object requires further in-depth analysis to identify determining factors and to analyze interdependencies. To obtain a more detailed 
understanding of these interdependencies, further research that builds on the proposed taxonomy is required. Especially research streams in management literature provide promising aspects to capture existing concepts, such as absorptive capacity (e.g. Cohen \& Levinthal, 1989, 1990; Lane \& Lubatkin, 1998), the relationship between internal and external innovation (e.g. Hillebrand \& Biemans, 2003), and proximity in cooperation (e.g. Knoben \& Oerlemans, 2006). Third, this paper focuses on general cooperation patterns on a higher level. Thus, we analyzed a large sample of cooperations and gathered information from public sources. Nonetheless, a more detailed case analysis of specific cooperations would reveal more insights about the intentions, such as contribution to the cooperation (e.g. expertise, data access, governance, shared processes, c.f. Dapp, 2014, 2015) or strategic objectives (e.g. trust, risk perception, or control, c.f. Das \& Teng, 2001). Further, especially for policy makers, our taxonomy can serve as a helpful classification of cooperation cases and their specific characteristics. Policy makers may examine and built upon the proposed cooperation patterns for the determination of legal actions. For instance, case-driven research approaches should match and analyze legislation for each of the proposed characteristics (e.g. banking licenses, antitrust legislation, patent law).

The theoretical contributions of the proposed classification artifact address the aforementioned research gap in three ways: First, in this paper, we laid the foundation for further research into fintechs and their integration into the banking sector. For this purpose, this paper can be considered a starting point in various research domains that will eventually analyze fintechs' roles and influences. For instance, finance researchers could be interested in the changes fintechs cause in the financial sector, economics researchers could further look into the consequences for the entire economy, or necessary policy changes. By addressing the development of a descriptive theory, our taxonomy depicts a crucial step towards a deeper understanding of the field, and the development of a higher-order theory (e.g. predictive theory, theory for design and action, cf. Gregor, 2006). Taking our taxonomy and its application as a basis, researchers will be able to focus on particular cooperation patterns and will be able to understand the specific characteristics and dynamics of the entire financial sector. Second, we have suggested the first range of relevant dimensions and characteristics that proven to be valid, useful, and effective. We have also presented prevailing cooperation patterns and identified dominant categories. The taxonomy's multidimensionality lays the foundations for analyzing interdependencies among the dimensions and characteristics - a future research area we find promising. For instance, banks and fintechs mostly form alliances; this can have consequences for banks' security risks, while fintechs indirectly gain access to a banking license, two aspects that are interesting for policy makers. Third, since digital transformation is increasingly accelerating developments in several economies and industries, similar phenomena are likely to similarly shape other industries. Thus, our work can serve as a guideline for other industries, in which similar challenges arise. For instance, in the automotive industry, car manufacturing companies still provide the engineering capabilities to build a car as a platform, but digital transformation enables other companies to provide new value for customers, for instance by providing apps for cars, driving software, and so on. Information systems are generally becoming increasingly important, since these changes are predominantly driven by information-based approaches, occur in organizational information systems, and demand cooperation across organizational borders. Thus, the research disciplines should be pioneers in understanding and providing explanations of the new phenomena arising from the digital transformation of the business world.

Besides our theoretical contributions, our taxonomy also provides valuable insights for practitioners in the banking industry. First, we propose a classification scheme for banking practitioners to evaluate their efforts at the interaction between banks and fintechs. Practitioners who apply our taxonomy can analyze their own endeavors in integrating fintechs and innovation, and can evaluate their value proposition within such cooperation. For this purpose, we delivered the key findings from a real-world database. Thus, managers can gain insights into the shared practices and related outcomes. Second, considering the number of cooperations, it is understood and instituted as an eligible strategy for promoting innovation. We also found 
that both parties benefit from the model, and complement each other's strengths and weaknesses. Third, fintechs play a crucial role and don't remain the silent, lesser partner in cooperations. Thus, alliances are the predominant form of cooperation in our empirical database, and acquisitions and incubations only play minor roles. The key role of the fintech is also underlined by the fact that the innovation mostly stays with the fintech. This allows for two contradictory interpretations, which require further verification: On the one hand, fintechs are unwilling to sell their innovation, and banks lack the opportunity to fully integrate a product or process into their organization. On the other hand, banks prefer to interact with fintechs as service providers, avoiding expensive and sophisticated integration efforts. This is also emphasized by the fact that both parties cooperate with numerous entities, which suggests that the modularity and interfaces, as well as the adaptability of business models, are key components to overcome future challenges. 


\section{References}

Accenture (2015). The Agile Bank - Transforming the Customer Experience. Retrieved from https://www.accenture.com/t20150916T152712_w__/us-en/_acnmedia/Accenture/ConversionAssets/Microsites/Documents19/Accenture-AgileBanking-Infographic.pdf\#zoom=50

Ahuja, G., \& Katila, R. (2001). Technological Acquisitions and the Innovation Performance of Acquiring Firms: A Longitudinal Study. Strategic Management Journal, 22(3), 197-220.

Alt, R., \& Puschmann, T. (2012). The rise of customer-oriented banking - electronic markets are paving the way for change in the financial industry. Electronic Markets, 22(4), 203-215. https://doi.org/10.1007/s12525-012-0106-2

Anand, B. N., \& Khanna, T. (2000). Do Firms Learn to Create Value? The Case of Alliances. Strategic Management Journal, 21(3), 295-315.

Ansari, S. S., \& Krop, P. (2012). Incumbent Performance in the Face of a Radical Innovation: Towards a Framework for Incumbent Challenger Dynamics. Research Policy, 41(8), 1357-1374.

Bailey, K. D. (1984). A Three-Level Measurement Model. Quality \& Quantity, 18(3), 225-245.

Bailey, K. D. (1994). Typologies and Taxonomies: An Introduction to Classification Techniques. Thousand Oaks, CA: Sage Publications.

Bajorat, A. M. (2015). Banken und FinTechs - Das Hecheln nach der Möhre kostet Zeit, Fokus und nimmt den großen Hunger. Retrieved from http://www.it-finanzmagazin.de/banken-und-fintechs-dashecheln-nach-der-moehre-kostet-zeit-fokus-und-nimmt-den-grossen-hunger-20330/

Barberis, J., \& Chishti, S. (Eds.). (2016). The FinTech Book: The Financial Technology Handbook for Investors, Entrepreneurs and Visionaries. Chichester, West Sussex, United Kingdom: John Wiley \& Sons Ltd.

Becker, W., \& Dietz, J. (2004). R\&D Cooperation and Innovation Activities of Firms - Evidence for the German Manufacturing Industry. Research Policy, 33(2), 209-223.

Behr, P., \& Schmidt, R. H. (2015). The German Banking System: Characteristics and Challenges.

Benlian, A., Hess, T., \& Leimeister, J. M. (2014). Business Models. Business \& Information Systems Engineering, 6(1), 45-53.

Berg, S. V., Duncan, J., \& Friedman, P. (1982). Joint Venture Strategies and Corporate Innovation. Cambridge, MA: Oelgeschlager, Gunn \& Hain.

Bergek, A., \& Norrman, C. (2008). Incubator Best Practice: A Framework. Technovation, 28(1), 20-28.

Bharadwaj, A., El Sawy, O. A., Pavlou, P. A., \& Venkatraman, N. (2013). Digital Business Strategy: Toward a Next Generation of Insights. Management Information Systems Quarterly, 37(2), 471-482.

Bøllingtoft, A., \& Ulhøi, J. P. (2005). The Networked Business Incubator - Leveraging Entrepreneurial Agency?,. Journal of Business Venturing, 20(2), 265-290.

Brynjolfsson, E., \& Hitt, L. M. (2000). Beyond Computation: Information Technology, Organizational Transformation and Business performance. The Journal of Economic Perspectives, 14(4), 23-48.

Cassiman, B., \& Veugelers, R. (2006). In Search of Complementarity in Innovation Strategy: Internal $\mathrm{R} \& \mathrm{D}$ and External Knowledge Acquisition. Management Science, 52(1), 68-82. https://doi.org/10.1287/mnsc. 1050.0470

Châlons, C., \& Dufft, N. (2017). The Role of IT as an Enabler of Digital Transformation. In The Drivers of Digital Transformation (pp. 13-22). Springer.

Chan, S. H., Kensinger, J. W., Keown, A. J., \& Martin, J. D. (1997). Do Strategic Alliances Create Value? Journal of Financial Economics, 46(2), 199-221.

Chandy, R. K., \& Tellis, G. J. (2000). The Incumbent's Curse? Incumbency, Size, and Radical Product Innovation. Journal of Marketing, 64(3), 1-17. 
Chen, J. S.J., \& Tsou, H.-t. (2006). Information Technology Adoption for Service Innovation Practices and Competitive Advantage: The Case of Financial Firms. Information Research, 12(3), 7.

Chesbrough, H. (2004). Managing Open Innovation. Research Technology Management, 47(1), 23-26.

Christensen, C. (2013). The Innovator's Dilemma: When New Technologies Cause Great Firms to Fail. Boston, MA: Harvard Business Review Press.

Cohen, W. M., \& Levinthal, D. A. (1989). Innovation and Learning: The Two Faces of R\&D. The economic journal, 99(397), 569-596.

Cohen, W. M., \& Levinthal, D. A. (1990). Absorptive Capacity: A New Perspective on Learning and Innovation. Administrative Science Quarterly, 128-152.

Dapp, T. M. (2014). Fintech - The Digital ®evolution in the Financial Sector: Algorithm-based Banking with the Human Touch.

Dapp, T. M. (2015). Fintech Reloaded - Traditional Banks as Digital Ecosystems: With Proven Walled Garden Strategies into the Future.

Das, T. K., \& Teng, B.-S. (2001). Trust, control, and risk in strategic alliances: An integrated framework. Organization studies, 22(2), 251-283.

Day, G. S. (1981). The Product Life Cycle: Analysis and Applications Issues. Journal of Marketing, 45(4), 60-67. https://doi.org/10.2307/1251472

Doty, D. H., \& Glick, W. H. (1994). Typologies as a Unique Form of Theory Building: Toward Improved Understanding and Modeling. Academy of Management Review, 19(2), 230-251.

Downes, L., \& Nunes, P. (2013). Big Bang Disruption. Harvard Business Review, 44-56.

Drucker, P. F. (1984). The Discipline of Innovation. Harvard Business Review, 63(3), 67-72.

Dyer, J. H. (1996). Specialized Supplier Networks as a Source of Competitive Advantage: Evidence from the Auto Industry. Strategic Management Journal, 271-291.

Dyer, J. H. (2000). Collaborative Advantage: Winning through Extended Enterprise Supplier Networks. New York, NY: Oxford University Press.

Economist Intelligence Unit. (2015). Strategic Partnerships for the Digital Age. Telstrea report. Retrieved from http://connectingcompanies.economist.com/whitepaper/about-the-report/

Ernst, D., Halevy, T., Monier, J.-H. J., \& Sarrazin, H. (2001). A Future for E-Alliances. The McKinsey Quarterly, 92.

Ernst \& Young (2011). The Digitisation of Everything: How Organisations Must Adapt to Changing Consumer Behaviour. Retrieved from http://www.ey.com/Publication/vwLUAssets/The_digitisation_of_everything__How_organisations_must_adapt_to_changing_consumer_behaviour/\$FILE/EY_Digitisation_of_ever ything.pdf

Fagerberg, J. (2004). Innovation: A Guide to the Literature. Proceedings of the the First Globelics Academy, Ph.D. School on National Systems of Innovation and Economic Development, Lisbon, Portugal, 1-26.

Fichman, R. G., Dos Santos, B. L., \& Zhiqiang, Z. (E.). (2014). Digital Innovation as a Fundamental and Powerful Concept in the Information Systems Curriculum. Management Information Systems Quarterly, 38(2), 329-343.

Fiedler, K. D., Grover, V., \& Teng, J. T. C. (1996). An empirically derived taxonomy of information technology structure and its relationship to organizational structure. Journal of Management Information Systems, 13(1), 9-34.

Glaser, F., \& Bezzenberger, L. (2015). Beyond Cryptocurrencies - A Taxonomy of Decentralized Consensus Systems. Proceedings of the European Conference on Information Systems, Münster, Germany. 
Glass, R. L., \& Vessey, I. (1995). Contemporary Application - Domain Taxonomies. IEEE Software, 12(4), 63-76.

Gregor, S. (2006). The Nature of Theory in Information Systems. Management Information Systems Quarterly, 30(3), 611-642.

Haas, P., Blohm, I., \& Leimeister, J. M. (2014). An Empirical Taxonomy of Crowdfunding Intermediaries. Proceedings of the International Conference on Information Systems, Auckland, New Zealand.

Hackett, S. M., \& Dilts, D. M. (2004). A Systematic Review of Business Incubation Research. The Journal of Technology Transfer, 29(1), 55-82.

Hagedoorn, J. (1993). Understanding the Rationale of Strategic Technology Partnering: Interorganizational Modes of Cooperation and Sectoral Differences. Strategic Management Journal, 14(5), 371-385.

Hagedoorn, J., \& Schakenraad, J. (1994). The Effect of Strategic Technology Alliances on Company Performance. Strategic Management Journal, 15(4), 291-309.

Harrigan, K. R. (1985). Strategies for Joint Ventures. Lexington, MA: Lexington Books.

Hevner, A. R., March, S. T., Park, J., \& Ram, S. (2004). Design Science in Information Systems Research. Management Information Systems Quarterly, 28(1), 75-105.

Hillebrand, B., \& Biemans, W. G. (2003). The Relationship Between Internal and External Cooperation: Literature Review and Propositions. Journal of Business Research, 56(9), 735-743.

Hippel, E. von. (2005). Democratizing innovation: The evolving Phenomenon of User Innovation. Journal für Betriebswirtschaft, 55(1), 63-78.

Hirt, M., \& Willmott, P. (2014). Strategic Principles for Competing in the Digital Age. McKinsey Quarterly, 1-13.

Hitt, M. A., Dacin, M. T., Levitas, E., Arregle, J.-L., \& Borza, A. (2000). Partner Selection in Emerging and Developed Market Contexts: Resource-based and Organizational Learning Perspectives. Academy of Management journal, 43(3), 449-467.

Hladik, K. J. (1985). International Joint Ventures: An Economic Analysis of US-Foreign Business Partnerships. Cooperative Strategies in Internation Business. Lexington Books: Lexington, MA.

Hladik, K. J. (1988). R\&D and International Joint Ventures. Cooperative Strategies in International Business, 187-204.

Hurley, R. F., \& Hult, G. T. M. (1998). Innovation, Market Orientation, and Organizational Learning: An Integration and Empirical Examination. Journal of Marketing, 62(3), 42.

Iivari, J. (2007). A Paradigmatic Analysis of Information Systems as a Design Science. Scandinavian Journal of Information Systems, 19(2), 5.

Jarillo, J. C. (1988). On Strategic Networks. Strategic Management Journal, 9(1), 31-41.

Jaubert, M., Marcu, S., Ullrich, M., Malbate, J.-B., \& Dela, R. (2014). Going Digital: The Banking Transformation Roadmap.

Jawahar, I. M., \& McLaughlin, G. L. (2001). Toward a Descriptive Stakeholder Theory: An Organizational Life Cycle Approach. Academy of Management Review, 26(3), 397-414.

Jöhnk, J., Röglinger, M., Thimmel, M., \& Urbach, N. (2017). How to Implement Agile IT Setups: A Taxonomy of Design Options. Twenty-Fifth European Conference on Information Systems (ECIS).

Kim, W. C., \& Mauborgne, R. (1997). Value Innovation. Harvard Business Review.

Knoben, J., \& Oerlemans, L.A.G. (2006). Proximity and Inter-organizational Collaboration: A literature review. International Journal of Management Reviews, 8(2), 71-89.

Kogut, B. (1988). Joint Ventures: Theoretical and Empirical Pperspectives. Strategic Management Journal, 9(4), 319-332. 
Koh, J., \& Venkatraman, N. (1991). Joint Venture Formations and Stock Market Reactions: An assessment in the Information Technology Sector. Academy of Management journal, 34(4), 869-892.

KPMG (2017). The Pulse of Fintech Q4 2016: Global analysis of investment in fintech. Retrieved from https://assets.kpmg.com/content/dam/kpmg/xx/pdf/2017/02/pulse-of-fintech-q4-2016.pdf

Lane, P. J., \& Lubatkin, M. (1998). Relative Absorptive Capacity and Interorganizational Learning. Strategic Management Journal, 19(5), 461-477.

Man, A.-P. de, \& Duysters, G. (2005). Collaboration and Innovation: A Review of the Effects of Mergers, Acquisitions and Alliances on Innovation. Technovation, 25(12), 1377-1387.

Mariotti, P., \& Ricotta, S. (1986). Diversification, Agreements Among Firms and Innovative Behaviour. Proceedings of the International Conference on Innovation Diffusion, Venice, Italy.

Mariti, P., \& Smiley, R. H. (1983). Co-operative Agreements and the Organization of Industry. The Journal of Industrial Economics, 31(4), 437-451.

Marous, J. (2013). Top 10 Retail Banking Trends and Predictions for 2014. Retrieved from http://thefinancialbrand.com/36367/2014-top-bank-trends-predictions-forecast-digital-disruption/

Matt, C., Hess, T., \& Benlian, A. (2015). Digital Transformation Strategies. Business \& Information Systems Engineering, 57(5), 339-343.

McKinnon, R. I. (1973). Money and Capital in Economic Development. Washington, DC: Brookings Institution, 1973; Shaw, E. Financial Deepening in Economic Development: New York: Oxford University Press.

Miller, G. A. (1956). The magical Number Seven, Plus or Minus Two: Some Limits on our Capacity for Processing Information. Psychological review, 63(2), 81.

Miller, J. G., \& Roth, A. V. (1994). A Taxonomy of Manufacturing Strategies. Management Science, 40(3), 285-304.

Mols, N. P. (1998). The Internet and the banks' strategic distribution channel decisions. Internet Research, 8(4), 331-337. https://doi.org/10.1108/10662249810231087

Moore, J. F. (1993). Predators and prey: A new ecology of competition. Harvard Business Review, 71(3), 75-83. Retrieved from http://blogs.harvard.edu/jim/files/2010/04/Predators-and-Prey.pdf

Moutinho, L., Davies, F., Deng, S., Miguel Peris, S., \& Enrique Bigne Alcaniz, J. (1997). The future role of bank branches and their managers: Comparing managerial perceptions in Canada and Spain.

International Journal of Bank Marketing, 15(3), 99-105. https://doi.org/10.1108/02652329710166019

Mowery, D. C., Oxley, J. E., \& Silverman, B. S. (1996). Strategic Alliances and Interfirm Knowledge Transfer. Strategic Management Journal, 17(S2), 77-91.

Nemet, G. F. (2009). Demand-Pull, Technology-Push, and Government-Led Incentives for NonIncremental Technical Change. Research Policy, 38(5), 700-709.

Nickerson, R. C., Varshney, U., \& Muntermann, J. (2013). A Method for Taxonomy Development and its Application in Information Systems. European Journal of Information Systems, 22(3), 336-359.

Nooteboom, B. (1999). Innovation and Inter-firm linkages: New Implications for Policy. Research Policy, 28(8), 793-805.

O’Connell, D. (2011). Harvesting External Innovation: Managing External Relationships and Intellectual Property. Surrey, UK: Gower Pubishing Limited.

Odedokun, M. O. (1996). Alternative econometric approaches for analysing the role of the financial sector in economic growth: Time-series evidence from LDCs. Journal of Development Economics, 50(1), 119-146. https://doi.org/10.1016/0304-3878(96)00006-5

OECD Oslo Manual. (2005). Proposed Guidelines for Collecting and Interpreting Technological Innovation Data. Paris.

Ohmae, K. (2002). Triad Power. New York, NY: The Free Press.

Olanrewaju, T. (2014). The Rise of the Digital Bank. McKinsey on Business Technology. (33). 
O'Riordan, N. (2013). Knowledge Creation: Hidden Driver of Innovation in the Digital Age. Proceedings of the International Conference on Information Systems, Milan, Italy.

Pisano, G. P., Shan, W., \& Teece, D. J. (1988). Joint Ventures and Collaboration in the Biotechnology Industry. Cambridge, MA: Ballinger Publishing Company.

Porter, M. E. (2001). The Technological Dimension of Competitive Strategy. In R. Burgelman \& H. Chesbrough (Eds.), Research on Technological Innovation, Management and Policy. Greenwich, CT: JAI Press.

Porter, M. E., \& Fuller, M. B. (1986). Coalitions and Global Strategy. Competition in Global Industries, $315,344$.

Powell, K., Koput, K. W., \& Smith-Doerr, L. (1996). Interorganizational Collaboration and the Locus of Innovation: Networks of Learning in Biotechnology. Administrative Science Quarterly, 41(1), 116145.

Püschel, L., Röglinger, M., \& Schlott, H. (2016). What's in a Smart Thing? Development of a Multi-Layer Taxonomy. $37^{\text {th }}$ International Conference on Information Systems (ICIS), 1-19.

Rich, P. (1992). The Organizational Taxonomy: Definition and Design. Academy of Management Review, 17(4), 758-781.

Rogers, E. M. (2003). The Diffusion of Innovation (Fifth Edition). New York, NY: The Free Press.

Sabherwal, R., \& King, W. R. (1995). An empirical taxonomy of the decision-making processes concerning strategic applications of information systems. Journal of Management Information Systems, 11(4), 177-214.

Saldaña, J. (2009). The Coding Manual for Qualitative Researchers. London: Sage.

Schmidt, R. H., \& Krahnen, J. P. (2004). The German Financial System: Oxford University Press.

Schmitt, H. O. (1974). Shaw, Edward S., Financial Deepening in Economic Development, New York, Oxford University Press, 1973 , xii +260 pp. (7.50 cloth, 3.50 paper). American Journal of Agricultural Economics, 56(3). Retrieved from https://EconPapers.repec.org/RePEc:oup:ajagec:v:56:y:1974:i:3:p:670.

Schultze, U., \& Avital, M. (2011). Designing interviews to generate rich data for information systems research. Information and Organization, 21(1), 1-16.

Schumpeter, J. A. (1942). Capitalism, Socialism, and Democracy. New York, NY: Harper and Row.

Schweizer, A., Schlatt, V., Urbach, N.,\& Fridgen, G. (2017). Unchaining Social Businesses-Blockchain as the Basic Technology of a Crowdlending Platform. $38^{\text {th }}$ International Conference on Information Systems (ICIS), Seoul, South Korea, 1-21.

Seo, M.-G., \& Hill, N. S. (2005). Understanding the Human Side of Merger and Acquisition an Integrative Framework. The Journal of Applied Behavioral Science, 41(4), 422-443.

Shontell, A. (2015). Jamie Dimon: Silicon Valley Startups are Coming to eat Wall Street's Lunch. Retrieved from http://www.businessinsider.com/jamie-dimon-shareholder-letter-and-silicon-valley2015-4?IR=T

Skan, J., Dickerson, J., \& Masood, S. (2015). The Future of Fintech and Banking: Digitally disrupted or reimagined? Retrieved from http://www.fintechinnovationlablondon.co.uk/media/730274/AccentureThe-Future-of-Fintech-and-Banking-digitallydisrupted-or-reima-.pdf

Takeishi, A. (2001). Bridging Inter-and Intra-firm Boundaries: Management of Supplier Involvement in Automobile Product Development. Strategic Management Journal, 22(5), 403-433.

Teece, D. J. (1987). Profiting from Technological Innovation: Implications for Integration, Collaboration, Licensing, and Public Policy. In D. J. Teece (Ed.), The Competitive Challenge (pp. 185-220).

Cambridge, MA: Ballinger Publishing Company.

Teece, D. J. (1992). Competition, Cooperation, and Innovation: Organizational Arrangements for Regimes of Rapid Technological Progress. Journal of Economic Behavior \& Organization, 18(1), 1-25. 
Teece, D. J. (2010). Business Models, Business Strategy and Innovation. Long Range Planning, 43(2-3), 172-194. https://doi.org/10.1016/j.lrp.2009.07.003

Thompson, V. A. (1965). Bureaucracy and Innovation. Administrative Science Quarterly, 10(1), 1-20.

Tilden, M. (1996). Channel vision. Retail Banker International, 28, 12-15.

Tilson, D., Lyytinen, K., \& Sørensen, C. (2010). Research Commentary - Digital Infrastructures: The Missing IS Research Agenda. Information Systems Research, 21(4), 748-759.

Tornjanski, V., Marinković, S., Săvoiu, G., \& Čudanov, M. (2015). A Need for Research Focus Shift: Banking Industry in the Age of Digital Disruption. Econophysics, Sociophysics \& Other Multidisciplinary Sciences Journal, 5(3), 11-15.

Tushman, M., \& Nadler, D. (1986). Organizing for Innovation. California Management Review, 28(3), 74-92.

Utterback, J. M., \& Abernathy, W. J. (1975). A Dynamic Model of Process and Product Innovation. Omega, 3(6), 639-656.

Van de Ven, A. H. (1986). Central Problems in the Management of Innovation. Management Science, 32(5), 590-607.

Walters, T. (2014). Beyond Marketing: Why Digital Disruption Requires a Deeper Transformation. Retrieved from Digital Clarity Group, Inc. website: https://cloudflare.acquia.com/sites/default/files/library/attachment/acquia_beyond-marketing.pdf

Wand, Y., Monarchi, D. E., Parsons, J., \& Woo, C. C. (1995). Theoretical Foundations for Conceptual Modelling in Information Systems Development. Decision Support Systems, 15(4), 285-304.

Williams, K., Chatterjee, S., \& Rossi, M. (2008). Design of emerging digital services: a taxonomy. European Journal of Information Systems, 17(5), 505-517.

Yaari, V. (1993). A Taxonomy of Disclosure Policies. Journal of Economics and Business, 45(5), 361374. https://doi.org/10.1016/0148-6195(93)90035-M

Yin, R. K. (2013). Case Study Research: Design and Methods. Thousand Oaks, CA: Sage Publications.

Yoo, Y. (2010). Computing in Everyday Life: A Call for Research on Experiential Computing. Management Information Systems Quarterly, 34(2), 213-231.

Yoo, Y., Boland Jr, R. J., Lyytinen, K., \& Majchrzak, A. (2012). Organizing for Innovation in the Digitized World. Organization Science, 23(5), 1398-1408. 


\section{Appendix I: Bank-Fintech Cooperations}

\begin{tabular}{|c|c|c|}
\hline ID & Bank & Fintech \\
\hline 1 & Fidor Bank AG & smava GmbH \\
\hline 2 & Fidor Bank AG & bankless24 GmbH \\
\hline 3 & FinTech Group Bank AG & ZINSPILOT (Deposit Solutions GmbH) \\
\hline 4 & Sparda-Bank & zencap (Funding Circle Deutschland GmbH) \\
\hline 5 & Comdirect Bank AG & moneymeets $\mathrm{GmbH}$ \\
\hline 6 & MHB-Bank AG & WeltSparen (Raisin GmbH) \\
\hline 7 & Deutsche Bank AG & Gini Pay (Gini GmbH) \\
\hline 8 & DAB BNP Paribas & $\begin{array}{l}\text { GINMON (Ginmon Vermögensverwaltung } \\
\text { GmbH) }\end{array}$ \\
\hline 9 & HypoVereinsbank (Unicredit Bank AG) & Gini Pay (Gini GmbH) \\
\hline 10 & DAB BNP Paribas & easyfolio $\mathrm{GmbH}$ \\
\hline 11 & Volksbanken & Startnext Crowdfunding GmbH \\
\hline 12 & Hauck \& Aufhäuser Privatbankiers AG & easyfolio $\mathrm{GmbH}$ \\
\hline 13 & ING-DiBa AG & Gini Pay (Gini GmbH) \\
\hline 14 & Wirecard AG & HOLVI (Holvi Payment Services Oy) \\
\hline 15 & Wirecard AG & zencap (Funding Circle Deutschland GmbH) \\
\hline 16 & net-m privatbank $1891 \mathrm{AG}$ & Vexcash AG \\
\hline 17 & Deutsche Kreditbank AG & FinReach $\mathrm{GmbH}$ \\
\hline 18 & Deutsche Kreditbank AG & WebID Solutions GmbH \\
\hline 19 & Consorsbank & Seedmatch crowdfunding GmbH \\
\hline 20 & Augsburger Aktienbank AG & moneymeets $\mathrm{GmbH}$ \\
\hline 21 & Fidor Bank AG & Bitcoin Deutschland AG \\
\hline 22 & Santander Consumer Bank AG & payever $\mathrm{GmbH}$ \\
\hline 23 & FinTech Group Bank AG & auxmoney $\mathrm{GmbH}$ \\
\hline 24 & Sparkasse Berlin & SumUp Payments Limited \\
\hline 25 & Comdirect Bank AG & Gini Pay (Gini GmbH) \\
\hline 26 & Wirecard AG & orderbird AG \\
\hline 27 & Deutsche Kreditbank AG & easyfolio $\mathrm{GmbH}$ \\
\hline 28 & Fidor Bank AG & FUNDSTER AG \\
\hline 29 & FIL Fondsbank GmbH & $\begin{array}{l}\text { Vaamo (Sciuridae Vermögensverwaltungs } \\
\text { GmbH) }\end{array}$ \\
\hline 30 & 1822 direkt & easyfolio $\mathrm{GmbH}$ \\
\hline 31 & Berliner Volksbank & simplesurance $\mathrm{GmbH}$ \\
\hline 32 & DZ Bank AG & iZettle \\
\hline 33 & DAB BNP Paribas & moneymeets $\mathrm{GmbH}$ \\
\hline 34 & FinTech Group Bank AG & Savedo GmbH \\
\hline 35 & Comdirect Bank AG & TopTrade \\
\hline 36 & Commerzbank AG & IDnow \\
\hline 37 & UBS Group AG & EASYSYS \\
\hline 38 & HypoVereinsbank (Unicredit Bank AG) & SumUp Payments Limited \\
\hline 39 & FinTech Group Bank AG & IDnow GmbH \\
\hline 40 & UBS Group AG & Figo GmbH \\
\hline 41 & Deutsche Kreditbank AG & Cringle GmbH \\
\hline 42 & VOBA Hellweg & Lendstar GmbH \\
\hline 43 & Berliner Volksbank & Bergfürst AG \\
\hline 44 & Commerzbank AG & Gini Pay (Gini GmbH) \\
\hline 45 & Comdirect Bank AG & easyfolio $\mathrm{GmbH}$ \\
\hline 46 & Consorsbank & easyfolio $\mathrm{GmbH}$ \\
\hline
\end{tabular}




\begin{tabular}{|c|c|c|}
\hline 47 & FinTech Group Bank AG & Qnips GmbH \\
\hline 48 & Commerzbank AG & Traxpay AG \\
\hline 49 & ING-DiBa AG & WebID Solutions GmbH \\
\hline 50 & FinTech Group Bank AG & talent-invest.de \\
\hline 51 & Süd-West-Kreditbank Finanzierung GmbH & auxmoney $\mathrm{GmbH}$ \\
\hline 52 & ebase & easyfolio $\mathrm{GmbH}$ \\
\hline 53 & Sutor Bank & fairr.de $\mathrm{GmbH}$ \\
\hline 54 & Sutor Bank & ZINSPILOT (Deposit Solutions GmbH) \\
\hline 55 & Augsburger Aktienbank AG & CASHBOARD \\
\hline 56 & Wirecard AG & RatePAY GmbH \\
\hline 57 & SWK Bank & WebID Solutions GmbH \\
\hline 58 & FIL Fondsbank GmbH & moneymeets $\mathrm{GmbH}$ \\
\hline 59 & Onvista media $\mathrm{GmbH}$ & easyfolio $\mathrm{GmbH}$ \\
\hline 60 & ING-DiBa AG & easyfolio $\mathrm{GmbH}$ \\
\hline 61 & FinTech Group Bank AG & easyfolio $\mathrm{GmbH}$ \\
\hline 62 & Wirecard AG & Lendico Deutschland GmbH \\
\hline 63 & Comdirect Bank AG & wikifolio Financial Technologies AG \\
\hline 64 & Commerzbank AG & CRX Markets GmbH \\
\hline 65 & Wüstenrot Bausparkasse AG & easyfolio $\mathrm{GmbH}$ \\
\hline 66 & Sutor Bank & FinReach GmbH \\
\hline 67 & Wirecard AG & SumUp Payments Limited \\
\hline 68 & Sparkassen-Finanzgruppe & Payone $\mathrm{GmbH}$ \\
\hline 69 & Commerzbank AG & Bilendo GmbH \\
\hline 70 & Commerzbank AG & ByeBuy Global Operations GmbH \\
\hline 71 & Commerzbank AG & OptioPay GmbH \\
\hline 72 & UBS Group AG & SumUp Payments Limited \\
\hline 73 & SEB AG & Tink GmbH \\
\hline 74 & SEB AG & Amelia \\
\hline 75 & SEB AG & Ripple \\
\hline 76 & SEB AG & Coinify \\
\hline 77 & SEB AG & Leasify \\
\hline 78 & Swedbank AB & Sprinklebit \\
\hline 79 & Danske Bank A/S & MobilePay \\
\hline 80 & $\begin{array}{l}\text { Hongkong \& Shanghai Banking Corporation } \\
\text { Holdings PLC }\end{array}$ & Tradeshift \\
\hline 81 & Santander Consumer Bank AG & iZettle \\
\hline 82 & Santander Consumer Bank AG & Kabbage Inc. \\
\hline 83 & Santander Consumer Bank AG & myCheck LLC. \\
\hline 84 & Santander Consumer Bank AG & Ripple \\
\hline 85 & Santander Consumer Bank AG & Socure \\
\hline 86 & Santander Consumer Bank AG & Monitise \\
\hline 87 & Santander Consumer Bank AG & Elliptic \\
\hline 88 & Santander Consumer Bank AG & SIGFIG \\
\hline 89 & Lloyds Banking Group plc & Worapay \\
\hline 90 & BNP Paribas & Hello bank! \\
\hline 91 & Banco Bilbao Vizcaya Argentaria & ATOM \\
\hline 92 & Banco Bilbao Vizcaya Argentaria & Holvi \\
\hline 93 & Banco Bilbao Vizcaya Argentaria & SpringStudio \\
\hline 94 & Banco Bilbao Vizcaya Argentaria & MADIVA \\
\hline 95 & Barclays PLC & analoganalytics \\
\hline
\end{tabular}




\begin{tabular}{|c|c|c|}
\hline 96 & Barclays PLC & thelogicgroup \\
\hline 97 & Barclays PLC & accesspay \\
\hline 98 & Royal Bank of Scotland & Oakam \\
\hline 99 & Royal Bank of Scotland & Funding Circle $\mathrm{GmbH}$ \\
\hline 100 & Royal Bank of Scotland & Assetz Capital \\
\hline 101 & Goldman Sachs Inc. & Square \\
\hline 102 & Goldman Sachs Inc. & Digital Asset \\
\hline 103 & Goldman Sachs Inc. & Funding Circle GmbH \\
\hline 104 & Goldman Sachs Inc. & CompareAsiaGroup \\
\hline 105 & Goldman Sachs Inc. & Nubank \\
\hline 106 & Goldman Sachs Inc. & Plaid \\
\hline 107 & Goldman Sachs Inc. & Bluefin Payment Systems \\
\hline 108 & Goldman Sachs Inc. & FreedomPay \\
\hline 109 & Goldman Sachs Inc. & UNX Inc. \\
\hline 110 & Goldman Sachs Inc. & Momo \\
\hline 111 & Goldman Sachs Inc. & Inveshare \\
\hline 112 & JP Morgan Chase \& Co. & Square \\
\hline 113 & JP Morgan Chase \& Co. & Avant \\
\hline 114 & JP Morgan Chase \& Co. & OpenFin \\
\hline 115 & Bank of Amerika Corp. & Yodlee \\
\hline 116 & Wells Fargo \& Company & EyeVerify \\
\hline 117 & Citigroup Inc. & Digital Asset \\
\hline 118 & Citigroup Inc. & Selerity \\
\hline 119 & Morgan Stanley & Square \\
\hline 120 & Morgan Stanley & SoFi \\
\hline 121 & Morgan Stanley & Affirm \\
\hline 122 & Morgan Stanley & Betabrand \\
\hline 123 & Morgan Stanley & Moneytree \\
\hline 124 & Santander Consumer Bank AG & Tradeshift \\
\hline 125 & Santander Consumer Bank AG & Digital Asset Holdings LLC. \\
\hline 126 & Santander Consumer Bank AG & PayKey \\
\hline 127 & UBS Group AG & Fantex Inc. \\
\hline 128 & UBS Group AG & UNX Inc. \\
\hline 129 & Banco Bilbao Vizcaya Argentaria & Coinbase.com \\
\hline 130 & Banco Bilbao Vizcaya Argentaria & Prosper Funding LLC. \\
\hline 131 & Banco Bilbao Vizcaya Argentaria & Personal Capital Co. \\
\hline 132 & Banco Bilbao Vizcaya Argentaria & Taulia GmbH \\
\hline 133 & Banco Bilbao Vizcaya Argentaria & Kasisto Inc. \\
\hline 134 & Barclays PLC & Square Inc. \\
\hline 135 & Deutsche Bank AG & Inxight Inc. \\
\hline 136 & Deutsche Bank AG & G2 Microsystems Inc. \\
\hline
\end{tabular}




\section{Appendix II: Taxonomy Development Iterations}

\begin{tabular}{|c|c|c|c|}
\hline Iteration & Name of dimension & $\begin{array}{l}\text { Approach } \\
\text { (C2E, E2C) }\end{array}$ & Included characteristics of the dimension \\
\hline 1 & Cooperation type & $\mathrm{C} 2 \mathrm{E}$ & Acquisition, alliance, incubation \\
\hline 2 & Innovation holder & $\mathrm{E} 2 \mathrm{C}$ & Bank, fintech \\
\hline 3 & $\begin{array}{l}\text { Maturity of the } \\
\text { innovation }\end{array}$ & $\mathrm{C} 2 \mathrm{E}$ & Introduction / uncoordinated, growth / segmental, maturity / systemic \\
\hline 4 & Entire taxonomy & $\mathrm{E} 2 \mathrm{C}$ & $\begin{array}{l}\text { No new characteristics, but additional input to better analyze the } \\
\text { banking system and new objects }\end{array}$ \\
\hline 5 & $\begin{array}{l}\text { Bank type / Value chain } \\
\text { location }\end{array}$ & $\mathrm{C} 2 \mathrm{E}$ & $\begin{array}{l}\text { Commercial bank, cooperative bank, savings bank / Customer } \\
\text { common interface, channel solutions and interaction platforms, } \\
\text { customer-oriented financial market infrastructure, core banking } \\
\text { systems, financial market infrastructure }\end{array}$ \\
\hline 6 & Fintech's maturity & E2C & Startup, emerging growth, mature stage \\
\hline 7 & $\begin{array}{l}\text { Bank's main distribution } \\
\text { channel / Business } \\
\text { ecosystem }\end{array}$ & $\mathrm{E} 2 \mathrm{C}$ & $\begin{array}{l}\text { Branches, online / Restricted by bank, restricted by fintech, restricted } \\
\text { by both, no restriction }\end{array}$ \\
\hline 8 & Fintech category & $\mathrm{E} 2 \mathrm{C}$ & API and Infrastructure, lending, payment \\
\hline 9 & Entire taxonomy & E2C & $\begin{array}{l}\text { No new characteristics, but additional inputs to better analyze the } \\
\text { literature on innovation types and new objects }\end{array}$ \\
\hline 10 & Innovation type & $\mathrm{C} 2 \mathrm{E}$ & Product, process \\
\hline 11 & Innovation type & E2C & Bank-to-customer process, customer-to-customer process \\
\hline 12 & $\begin{array}{l}\text { Fintech holding a full } \\
\text { banking license / } \\
\text { Fintech category }\end{array}$ & $\mathrm{E} 2 \mathrm{C}$ & Yes, no / Investing, current account, insurance \\
\hline 13 & Cooperation type & E2C & Joint venture \\
\hline 14 & $\begin{array}{l}\text { Bank's strategic } \\
\text { objective }\end{array}$ & $\mathrm{E} 2 \mathrm{C}$ & Technology access, market access \\
\hline 15 & Bank's role & E2C & Services consumer, services provider \\
\hline 16 & $\begin{array}{l}\text { Fintech category / } \\
\text { Bank's role }\end{array}$ & $\mathrm{E} 2 \mathrm{C}$ & Cross-product services / Investor \\
\hline 17 & Entire taxonomy & $\mathrm{E} 2 \mathrm{C}$ & - \\
\hline
\end{tabular}

